\title{
De vilde, de erotiske \\ og de røveriske
}

\section{Folkeudstillinger med arabere og muslimer i København og Aarhus i perioden 1876-1909}

af GARBI SCHMIDT denne artikel vil jeg beskrive nogle begivenheder, som omkring
år 1900 eksponerede den danske befolkning for den arabiske og muslimske verden. Som Jørgen Bæk Simonsen blandt andet har beskrevet i bogen Islam med danske øjne. Danskernes syn på islam gennem 1000 år, så er islam eller personer og grupper, som repræsenterede denne religion, ikke et nyt fænomen i den danske offentlighed (Simonsen 2004:10). I denne artikel vil jeg udbrede perspektivet til at se både på den danske offentligheds møde med islam og den arabiske verden. Jeg vil endvidere se på, hvordan nogle møder så ud indenfor Danmarks grænser. Denne artikels fokus vil derfor være på folkeudstillinger, som præsenterede den arabiske og muslimske verden for et dansk publikum, i henholdsvis København og Aarhus, i perioden 18761909. Udstillingerne byggede som sådan på samtidens fortællinger om det eksotiske og erotiske Orienten, men samtidigt var udstillingerne et rum, som gav besøgende mulighed for (mod betaling) at møde mennesker fra den arabiske og muslimske verden ansigt til ansigt. Hertil kommer, at selvom artisterne var engagerede til udstillinger og kun blev i Danmark korte perioder, var deres tilstedeværelse ikke kun begrænset til udstillingernes afgrænsede område. Offentligheden har kunne møde dem i bybilledet, hvilket artiklen også vil give eksempler på. Såvel udstillingerne og de møder som de førte med sig, har haft betydning for, hvordan henholdsvis den københavnske og aarhusianske befolkning kom til at forstå islam og arabisk kultur. 


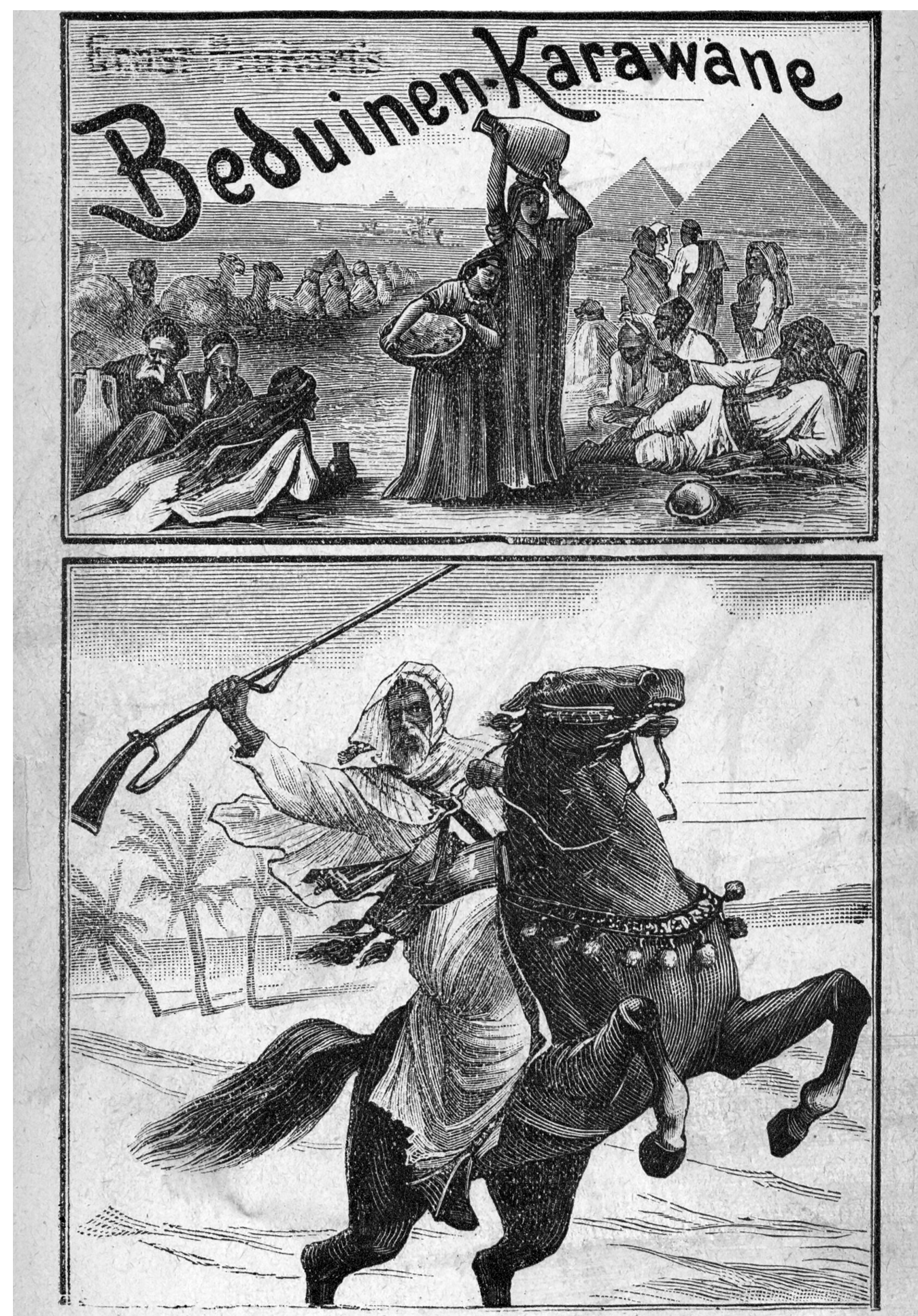


Til artiklen er anvendt forskellige typer af kilder. En vigtig kilde er databasen Mediastream, som er det Kongelige Biblioteks mediesamling, som blandt indeholder artikler fra danske dagblade fra 1666 og fremefter. Det må dog understrege, at det store projekt med ind-scanning af danske avisartikler i Mediastream endnu ikke er afsluttet, og at der således ikke kunne dannes et komplet overblik over alle de artikler, som har behandlet emnet. Anvendte søgeterme var «muslim», «islam», «araber», «musulman», «beduinerkaravane», «mavedans», enten som selvstændige søgetermer eller kombineret med ordene «København», «Aarhus» eller «Tivoli». Derudover blev der søgt på begivenheder, udstillinger og optrædener, hvor jeg $\odot \odot \odot$

«[...] hvis Medlemmer gælde for at være dristige forvovne Ryttere, gode Skytter og uforbederlige Røvere, med Ørkenens

Beboeres ejendommelige Karakter [...].» $\odot \odot \odot$

allerede vidste, at personer med arabisk og/eller muslimsk baggrund havde optrådt: «Abessiniernes Landsby», «Landsudstillingen», «BeduinenKarawane», «Beduiner-Karavane» og «Mahdiens Krigere». Yderligere begivenheder, som blev fundet igennem mine søgninger var udstillingerne «Haremet» og «Baghdad i Tivoli», som fandt sted $\mathrm{i}$ henholdsvis 1896 og 1907. Disse to begivenheder bliver dog ikke behandlet i nærværende artikel, selvom de fremstillede «Arabien» og Orienten. De engagerede nemlig ikke arabiske artister. ${ }^{1}$ Lignende søgninger blev foretaget i dagbladet Politikens online arkiv, da dette dagblads artikler ikke indgår i Mediestream. I alt blev der, på baggrund af disse søgninger, downloadet 75 avisartikler til videre analyse.

Udover fremstillingerne i de danske dagblade, er der i artiklen blevet anvendt de kataloger, som blev udarbejdet til to af udstillingerne, nemlig
«Beduinen-Karawane» i København i 1892 og «Abessiniernes Landsby» i Aarhus i 1909. Ligeledes er det fotomateriale, som viser abessiniernes lejr blevet unders $\varnothing \mathrm{gt}$ (Landsudstillingens Bureau). Der forefindes desværre ikke lignende materiale fra andre beduiner-karavaner i $\mathrm{K} \varnothing$ benhavn i perioden.

Udover introduktionen har denne artikel fire dele. Den første beskriver udstillingernes og karavanernes baggrund. Derefter følger tre afsnit, som beskriver og analyserer nogle fremtrædende temaer i det indsamlede datas beskrivelse af udstillingerne og karavanerne: 1 ) araberne som vilde, røverisk og frast ødende, 2) araberne som eksotiske og seksualiserede, og 3) araberne og deres religiøse praksis. Artiklens fjerde afsnit indeholder den afsluttende diskussion. Teoretisk henter artiklen inspiration fra Edward Saids klassiske værk Orientalisme (Said 1979) og fra særligt Rikke Andreassens arbejde med menneskeudstillinger $\mathrm{i}$ dansk og europæisk sammenhæng. ${ }^{2}$ En diskussion af menneskeudstillings og/eller folkeudstillingsbegrebet er dog nødvendig, og findes i følgende afsnit.

Perspektivet på orientalisme er vigtige for at forstå udstillingerne af mennesker fra den arabiske og islamiske verden i slutningen af det 19. og begyndelsen af det 2o. århundrede, og folkeudstillingerne som sådan. Orientalisme kan, ifølge Said både ses som a) et verdensbillede, der skaber en ontologisk og epistemologisk distinktion imellem Orienten og Occidenten; en måde, b) hvorpå en anden kunne domineres på, og c) et akademisk felt. Såvel verdensbillede og (ret til) dominans vil indgå $i$ artiklens analytiske afsnit, og understreges af selve fænomenet «folkeudstilling» som sådan. Nogle grupper af mennesker blev udstillet, andre blev ikke; nogle grupper af mennesker blev beskuet og studeret, andre mennesker beskuede og studerede. Det sidste element, det akademiske felt, er ikke mindst tydeligt i den måde, hvorpå udstil- 
lingernes kvalitet blev underbygget på. I kataloget til udstillingen «Beduinen-Karawane» i København i 1892, som beskriver udstillingen som et eksempel på etnografi:

Ogsaa det her foreliggende Foretagende danner en betydningsfuld Begivenhed $i$ de etnografiske Udstillingers Historie da det gør Europaeren bekendt med en afrikansk Menneskerace, hvis Medlemmer galde for at vare dristige forvovne Ryttere, gode Skytter og uforbederlige Rovere, med $\emptyset$ rkenens Beboeres ejendommelige Karakter, med en af Nordafrikas originaleste og besynderligske Folketyper («Beduinen-Karawane» 1892:4. Min fremhavelse).

Det må understreges, at ikke al såkaldt orientalistisk forskning i perioden passer ind i det mønster, som Said har beskrevet. Jørgen Bæk Simonsen $\mathrm{g} ø \mathrm{r}$ da også i bogen Islam med danske øjne opmærksom på, at der findes undtagelser blandt danske forskere. Der var forskere (og Simonsen behandler Johannes Østrups arbejde i detaljer) som var både respektfulde og ikke-dømmende i mødet med kulturelle og religiøse forskelligheder. Her er det værd at se på, hvordan forskellige forskningstraditioner i samtiden i det hele taget forholdt sig til «Den Anden». Hvor Bæk Simonsen fx diskuterer orientalismen som videnskabelig tradition, forholder en forsker som Rikke Andreassen sig blandt andet til periodens racevidenskab: Et tankegodt, som i øvrigt også havde betydning for de perspektiver, som udviklede sig indenfor akademiske discipliner som antropologi og etnologi (se fx Stocking 1982). Andreassen beskæftiger sig med, hvordan man atter i slutningen af 180o-tallet og begyndelsen af 1900-tallet forskningsmæssigt arbejdede ud fra idéen om mennesker som hierarkisk opdelt i racer. Folkeudstillinger, ikke mindst af personer fra den arabiske og muslimske verden, kan siges at bygge på både orientalisme og racevidenskab. Hertil kommer et $\emptyset$ konomisk perspektiv: Folkeudstil- lingerne var en del af samtidens underholdningsindustri, og en måde, hvorpå driftige forretningsmænd og etablissementer kunne tjene penge. Dette gjaldt ikke bare i Danmark, men også internationalt (se fx Hodeir 2014).

\section{Udstillingernes og karavanernes baggrund}

Perioden ca. 1880-1910 kan beskrives som folkeudstillingernes og-karavanernes tidsalder. Indenfor dansk forskning har særligt Rikke Andreassen som allerede nævnt beskæftiget sig med sådanne udstillinger (fx Andreassen \& Henningsen 2011; Andreassen 2015). Jeg vil, i lighed med historikeren Per Nielsen, kalde disse udstillinger for folkeudstillinger (Nielsen 2015: 273ff), da udstillingerne fokuserede på folkeslag og hvad der blev set som disses etniske og nationale egenart. Ligeledes vil jeg via begrebet understrege, at var tale om en udstillingsindustri, hvor deltagernes etniske og nationale baggrund blev brugt som salgsargument, men hvor dette salgsargument nogle gange spillede en underordnet, andre gange overordnet rolle i udstillingen. Her må det understreges, at ordet udstilling ifølge Den Danske Ordbog defineres som et «arrangement hvor man for et (betalende) publikum fremviser en udvalgt række af seværdige genstande eller individer». ${ }^{1}$

Andreassens og kollegaen Anne Folke Henningsens forskning har vist, hvor udbredt udstillingerne var, og hvor forskellige folkeslag, som blev udstillet. De oplister i alt 56 folke-/menneskeudstillinger i Danmark i perioden 1878-1909. Udstillingerne indbefattede nubier, marokkaner, japanere, kinesere, samere, indere, siouxindianere og afrikanere). Andreassen og Henningsen understregede selv i deres diskussion af listen, at den ikke måtte anses for komplet, og flere udstillinger helt sikkert kunne tilføjes. Efterfølgende har digitalisering af historiske danske aviser, som siden 2014 er blevet udført af Statsbiblioteket og Det Kongelige Bibliotek, betydet, at det er blevet 
nemmere at søge i kilderne. Det er dermed lettere at finde frem til sådanne udstillinger, hvilket nærværende artikel også understreger. Et eksempel på en udstilling, som ikke findes på Andreassens og Henningsens liste, er en udstilling af kinesere, som fandt sted i Panoramabygningen på Rådhuspladsen i København i 1897 (Rasmussen \& Schmidt 2021). Et andet eksempel, som beskrives mere indgående i denne artikel, fandt sted i 1892. Hidtil har forskningen hævdet, at udstillingen, som hed Beduinen-Karawane, fandt sted i Tivoli (fx Andreassen 2003; Andreassen \& Henningsen 2011). Men udstillingen fandt faktisk sted på en grund mellem Bernstorffsgade og Reventlowsgade. I samme periode havde Tivoli bes $\emptyset \mathrm{g}$ af arabertruppen Hadj Abdullah. Der var altså tale om to konkurrerende kompagnier/udstillinger, som geografisk var placeret meget tæt på hinanden.

Som nævnt havde udstillingerne forskellige format, men delte en måde at se grupper af mennesker på, via en forståelse af disse som hierarkisk opdelt i racer. Nogle mennesker kunne udstilles ved siden af vilde dyr i en zoologisk have eller i en forlystelsespark, fordi de var «vilde» og «naturbørn». Sådanne begreber blev også brugt om de udstillede fra den arabiske og muslimske verden. I kataloget til beduiner-karavanen i København i sommeren 1892 præsenteres folkeudstillingernes formål som følger:

Det Foretagende, at rykke Reprasentanter for enkelte Folkegrupper af vildere eller mere halvbarbariske Slags narmere til Kulturmennesket og fremstille dem $i$ deres ejendommelige Levevis, har skabt hine store etnografiske Udstillinger, som $i$ Aarrakker har bestrabt sig for $i$ rig Afvexling at bringe Typer af Indfødte fra alle Verdensdele og Landstrøg til at give Møde på den hjemlige Jordbund (Beduinen-Karawane 1892: 4. Min fremhavelse)

Anvender man Andreassens og Henningsens liste, kombineret med resultater fra de avissøgninger, som er udført til denne artikel, blev ti folkeudstillinger med artister fra arabisktalende og muslimske lande afholdt i København og Aarhus imellem 1876-1909:

1876 | Araberselskabet af Stammen Beni-Hagji og Negere fra Marokko

TIVOLI

1880 | Marokkansk Troup

TIVOLI

1892 | Araber Troupe, Hadj Abdullah ${ }^{3}$

TIVOLI

1892 | Beduinen Karawane

BERNSTORFFSGADE / REVENTLOWSGADE

1895 | Araber Trup Hadj Abdullah

CIRKUS OG NATIONALS VARIETÉER

1897 | Araber Trup Hadj Abdullah

CIRKUS VARIETÉ

1897 | Beduiner Karavane

TIVOLI

1899 | Mahdiens Krigere 4

TIVOLI

1901 | Beduiner Karavane

TIVOLI

1909 | Abessiniernes Landsby

LANDSUDSTILLINGEN I AARHUS

Udstillingerne kunne variere når det gjaldt indretningen af det fysiske rum og de aktiviteter, som fandt sted i forbindelse med dem. Til udstillingen «Abessiniernes Landsby» ved Landsudstillingen $\mathrm{i}$ Aarhus i 1909, blev der bygget både hytter, værksteder, og en (koran)skole for at give de besøgende en fornemmelse af (eksotisk) hverdagsliv i lande, langt væk fra Danmark. I andre tilfælde, som fx de to beduiner-karavaner, som besøgte København i 1892 og 1897, var der lagde større vægt op optrædener, som tilskuerne kunne iagttage fra tribuner. Disse forestillinger var dog kombineret med andre aktiviteter. Ved beduiner-udstillingen København i 1892 var der værksteder, hvor be- 


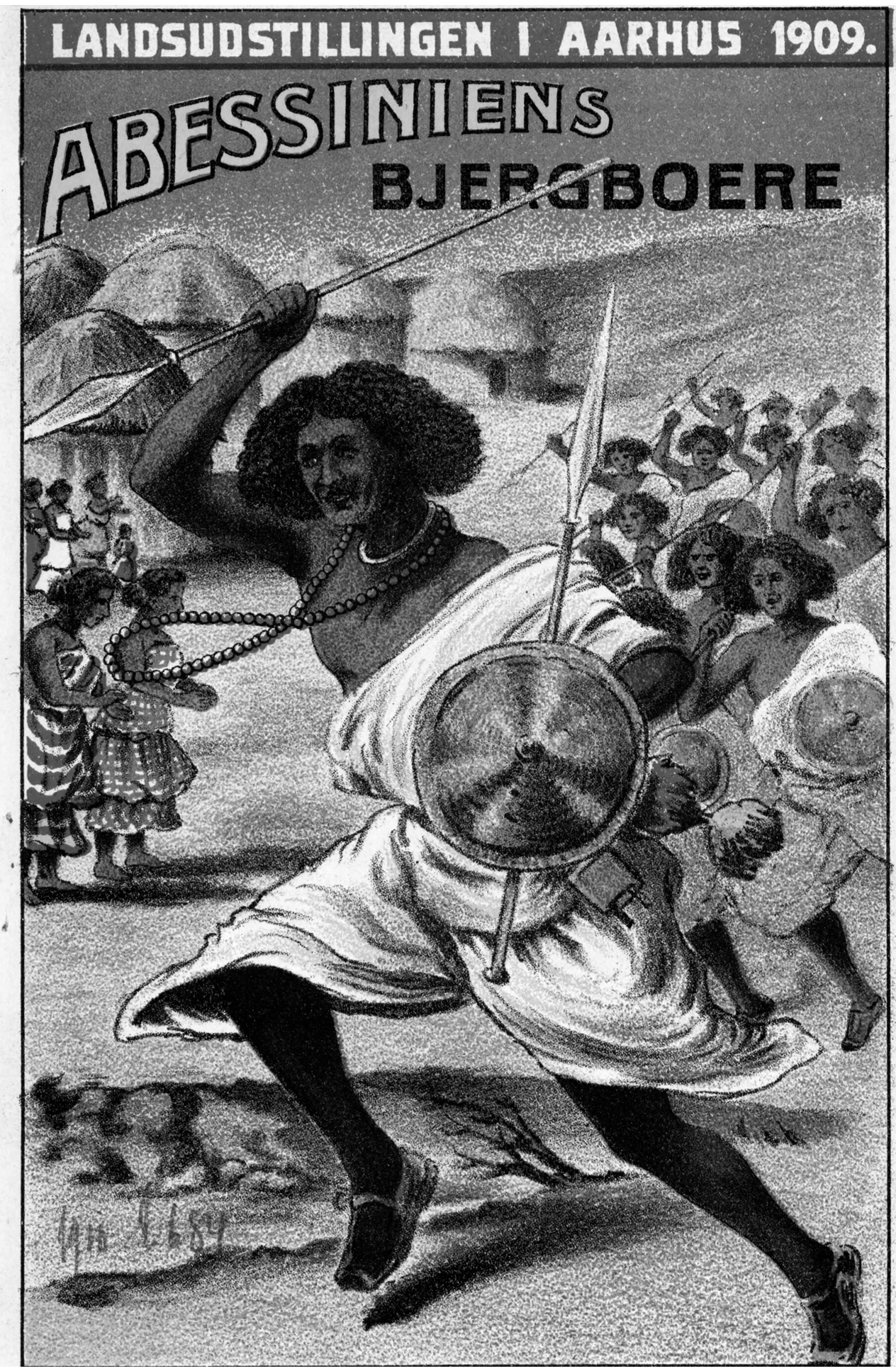


søgende kunne se på fabrikation af perlemors- og bronzearbejde og besøge et snedkeri (Morgenbladet København 1892). Ved beduiner-udstillingen i Tivoli i 1897 blev det i pressen rapporteret, at truppen havde medbragt både telte og basarer (Ribe Stifts-Tidende 1897). Ved begge typer af udstillinger var der fokus på at fremhæve bestemte fortællinger om bestemte folkeslag. Fortællingerne blev forstærket igennem etablering af tableauer, malede dekorationer, og opsatte palmer (fx Morgenbladet København 1892). Ofte talte udstillingerne også dyr. I forbindelse med beduinerkaravanerne i København i 1892, 1897 og 1901 blev der både vist heste, dromedarer, $\varnothing$ rkenhunde og såkaldte «Mekkaæsler» (se fx «Hjort» 1892; «Moustache» 1901).

Folkeudstillingerne kunne tage form af rene cirkusforestillinger, ofte med vild akrobatik. Men også i disse tilfælde var artisternes kulturelle og etniske baggrund noget, der blev fremhævet. Pressen kunne således skrive om arabiske artisters linedans og akrobatiske øvelser, samtidigt med, at de i beskrivelserne lagde vægt på artisternes «Araberhyl» og fremmedartede udseende. «De er Kjønne Folk, de Arabere», som det hed i en artikel om truppen Hadj Abdullahs optræden i Tivoli i 1892. Artiklen bemærkede dog også: «Deres Præstationer er ikke så overraskende, som man havde forventet det af virkelige Arabere.» (Kjøbenhavns Adressecomptoirs Efterretninger 1892). Endvidere blev der $i$ annoncer for forestillinger $-\mathrm{fx}$ ved Trup Hadj Abdullahs optrædener i København i 1895 og 1897 - konsekvent gjort opmærksom på, at der var tale om «arabere» og/eller «den bedst eksisterende Araber-Trup» (København 1897). Selvom hovedtemaet var akrobatik, var et vægtigt salgsargument således artisternes etniske baggrund.

Samtidens forståelse af menneskeracer var, som beskrevet, en vigtig forudsætning for at folkeudstillingerne opnåede deres popularitet. For udstillingerne formåede at trække et stort publikum. Fx trak udstillingerne af henholdsvis senegalesere og «Mahdiens Krigere» i Tivoli i 1899 et publikum på i alt 96.741 personer (Social-Demokraten 1899). At der var tale om en ganske givtig forretningsmodel understreges også af, at de forskellige trupper og karavaner ofte rejste flere steder hen i Europa, og at folkekaravanerne derfor kunne være i konkurrence med hinanden, hvis de dukkede op samtidigt på samme sted (Lolland-Falsters StiftsTidende 1892). At der var tale om udstillinger, som det var værd at besøge, blev i pressen ofte fremhævet ved, at der var blevet brugt anseelige beløb på både indretning og artister. Derudover var det et yderligere aspekt af udstillingernes tiltrækningskraft, at de som nævnt indeholdt forskellige typer af aktiviteter som både optræden,

$$
\odot \odot \odot
$$

«Undertiden bliver den kvindelige Paatrængenhed saa hed og nærgaaende at de Sorte ligefrem maa benytte magt for at befri sig for de 'kulrede’ Damer.» ๑॰

basarer, værksteder og kaffesaloner (fx Den til Forsendelse med de Kongelige Brevposter privilegerede Berlingske Politiske og AdvertissementsTidende 1892; Dannebrog 1897b). At nogle af karavanerne havde rejst Europa tyndt kunne bruges til at underbygge udstillingernes hævdelse af, at de præsenterede autentisk og ægte fremmed kultur, ikke mindst hvis de havde tiltrukket prominente gxster.

I Beduinen - Officielt Organ for BeduinerLejren i Danmark (1892) blev det således fremhævet, at Karavanen, under sit besøg i Berlin, havde haft den ære at få bes $\emptyset \mathrm{g}$ af selveste Kejser Wilhelm II og Kejserinde Friderich. Men havde udstillingernes deltagere opholdt sig for længe i «civilisationen» (altså, på det europæiske kontinent), kunne det også have en devaluerende effekt på deres troværdighed. Der blev således i 
både udstillingskataloger og dagspressen lagt vægt på, at det $\mathrm{i}$ forberedelsen af udstillingerne var forsøgt at komme så tæt på den «ægte vare» som overhoved muligt. I forbindelse med annonceringen af beduiner-karavenen på Bernstorffsvej i 1892 skrev Kjøge Avis således at «det ikke er en almindelig Arabertrup, der for en billig Penge rejser omkring og gjør Kunster for en sparsom Tilskuerkreds under et interimistisk Rejsetelt». Avisen understregede tillige, at eksisterende udenlandske anmeldelser fremhævede, at «hvad vi som Børn have læst og beundret på Billeder, have vi her i håndgribelig virkelighed for os» (Kjøge Avis 1892a). Også det udstillingskatalog, som blev udgivet i forbindelse med «Abessiniernes Landsby» på Landsudstillingen i Aarhus, gjorde en dyd ud at understrege, at udstillingen præsenterede noget autentisk: «Med ubetinget Naturtroskab er Landsbyen opført, og man glemmer næsten, at man befinder sig i Europas civilisation ... Alt er nøjagtigt som i hjemlandet» (Landsudstillingen i Aarhus 1909: 3). Jagten på det autentiske indebar ofte, at driftige forretningsmænd eller impresarier rejste til både Asien, Mellemøsten og Afrika for at hente artister og trupper direkte derfra. Et eksempel på sådanne aktiviteter finder vi i beskrivelsen af optakten til beduiner-karavanen i Tivoli i 1897, hvor avisen Dannebrog allerede i februar måned skriver, at:

Vores Lasere ved ogsaa, at den tyske Direktør og Impresario Hr. W. Møller for Øjeblikket opholder sig $i$ Kairo for at sammensatte Karavanen. Saa snart dette er lykkedes, vil Hr. Møller gjøre Tivoli et Tilbud, som rimeligvis vil blive akcepteret (Dannebrog 1897a)

Medlemmerne af de fire folkekaravaner, som særligt diskuteres i denne artikel, kom fra forskellige lande i det nordlige og østlige Afrika og Mellem$\emptyset$ sten. For eksempel indbefattede beduinerkaravanen på Bernstorffsvej i København i 1892 «repræsentanter for 'Banden' Nem-Rahsi af Stammen 'Mograbi', som gennemstrejfer det mellem Nilen, Middelhavet og Barka beliggende Del af Nedre-Ægypten» («Beduinen-Karawane» 1892: 4). Og udstillingen «Mahdiens Krigere» indbefattede en arabisktalende trup, som kom fra Sudan, og som ved deres ankomst til København fra Kiel, under ledelse af den tyske impresario R. Lind, allerede havde været undervejs i et år (København 1899).

I de følgende tre afsnit vil jeg præsentere nogle af de temaer, som syntes at gennemsyre de folkeudstillinger, som præsenterede artister fra den arabiske og muslimske verden. ${ }^{6}$ Tematikkerne syntes i særlig grad at kredse om de udstilledes vildskab, røveriskhed og erotiske tiltrækningskraft. Arabere og muslimer lå, når man sammenligner med fremstillingerne i andre udstillinger, ikke absolut i bunden af det racemæssige hierarki (her lå ikke mindst «kannibaler» og «negre»), men de lå heller ikke i toppen. En gruppe, som havde særligt rang var kineserne, som i samtiden måske nok blev beskrevet som kuriøse, barnlige og erotisk tiltrækkende, men også som «den gule fare» og dermed både snedige, farlige og intelligente (Rasmussen \& Schmidt 2021). Her blev arabere og muslimer forstået som tilhørende en anden og lavere kategori.

\section{Araberne som røveriske, vilde og frastødende}

Såvel dagspressen og udstillingskatalogerne fremstillede deltagere i folkeudstillinger fra arabiske og muslimske lande som vilde og røveriske mennesker. Et eksempel, som allerede er nævnt, er kataloget «Beduinen-Karawane»s (1892) beskrivelse af karavanens deltagere som «uforbederlige Røvere». Tematikken om røveriskhed blev direkte kædet sammen med de udstilledes identitet. Således interviewede pseudonymet «Brian» i en artikel, der blandt andet bringes i Bornholms Avis og Amtstidende i 1892 (i forbindelse med be- 
duiner-karavanen) hvem der betegnedes som karavanens «høvding». Skribenten introduceres til høvdingen igennem en af «Karavanens økonomiske Direktører», som i øvrigt beskrives som «en Muselman med udprægede jødiske Træk». I beskrivelsen af Sheikhen lagdes der vægt på dennes røveriskhed:

Scheik Tarriff er en ganske almindelig og ordinar Røver, hvis Bedrifter staar paa Højde med de bekendteste europaiske; han har hele sit Liv foragtet den lille Forskel, der er paa Mit og Dit, og for øvrigt uddelt Dolkestød med en Rigmands Rundhaandethed. ("Brian"1892)

At karavanernes deltagere var at anse for røvere, betonedes også af en artikel i Politiken i 1892, som sigende bar overskriften «Ørkenrøvere i Reventlowsgade» («Moustache» 1892). Beslægtet med forståelsen af araberne som røvere var forståelsen af disse som snydere og tiggere. Således beskriver «Moustache» i Politiken i 1897, hvordan et af børnene i årets udstilling både tiggede overfor og prøvede at snyde journalisten («Moustache» 1897). Og dagbladet Dannebrog advarede inden 1897 udstillingen om, at der kunne forekomme en gentagelse af det snyderi med souvenirs, som avisen hævdede at tyrkiske og syriske købmænd «af allerlaveste Rang» havde stået for under beduiner-karavanen i 1892 (Dannebrog 1897c).

At de udstillede arabere ikke kun ansås for at være røveriske, men også uregerlige og vilde, er også et tilbagevendende tema i avisartiklerne. Krigeriskhed og vildskab var et centralt element i den optræden, som blev udført i forbindelse med udstillingerne. «Overfald på en karavane», «dødsridt» og «hestetyveri» var fx elementer $i$ udstillingen i Tivoli i 1897 (fx Dannebrog 1897b), og kampspil og krigsdanse var på programmet ved abessiniernes lejr i Aarhus i 1909 (Landsudstillingen i Aarhus 1909:4). Derudover rapporterede flere dagblade i forbindelse med beduiner- karavanens ankomst til København i 1892, at nogle af truppens medlemmer, efter at der var blevet tændt bål og indtaget en del snaps, var kommet op at slås «under høje Brøl og Skrig, der satte hele Kvarteret i Skræk». Politiet prøvede at gribe ind, dog uden større effekt. «Først efter at have afsluttet deres blodige Mellemværende trak de sig på Sheikhens Befaling tilbage til deres Huler» (Kolding Folkeblad 1892). At ordet «huler» brugtes som betegnelse for karavane-deltagernes indkvartering er i den forbindelse bemærkelsesværdig. Her var vitterligt tale om vilde mennesker!

\section{Araberne som eksotiske og seksualiserede}

Blikket på de udstillede som eksotiske og seksualiserede indbefattede en dobbelttydighed. På den ene side blev de - som jeg vil beskrive herunder - set på som så tiltrækkende, at særligt kvindelige tilskuere havde svært ved at holde sig fra dem. Samtidigt blev det i nogle af artiklerne fremhævet, at de udstillede var både grimme og frastødende. Pseudonymet «Blodin» skriver om udstillingen «Mahdiens Krigere» i Kjøbenhavns Adressecomptoirs Efterretninger, at:

Krigerne er høje og magre, Kvinderne gjennemgaaende uformeligfede [...] Mandene er overmaade grimme, med vilde og frastødende Ansigter, som dog ved en ringe Anledning oplyses i lutter Smil. («Blodin» 1899)

I størstedelen af artiklerne beskrives artisterne som kendetegnede ved en ofte uimodståelig erotisk tiltrækningskraft. Et tilbagevendende element var kvindernes mavedans (fx Kjøge Avis 1892; Dannebrog 1897b). Af mindst lige så stor interesse var alliancerne mellem udstillede mænd og danske kvinder. Et (empatisk) indslag herom blev bragt i Kjøge Avis i 1892 underoverskriften «Giftelysten Araber» (Kjøge Amtsavis 1892c). Historiens baggrund var, at et medlem af den araber-trup, som optrådte i Tivoli selvsamme sommer, ville 
gifte sig med sin danske forlovede. For, som der stod i artiklen: «De unge Ørkens $\varnothing n n e r$ gjør nemlig ligesom deres Landsmænd [i] Beduinlejren i Bernstorffsgade, stormende Lykke hos det smukke Kjøn.» Vielsen, skulle finde sted på Københavns Rådhus (det blev understreget, af den unge araber bekendte sig til «Profeten Muhameds Lære», og $\odot \odot \odot$

«Kvinderne [er] uformelig fede. Mændene er overmaade grimme, med vilde og frastødende Ansigter, som dog ved en ringe Anledning oplyses i lutter Smil.»

๑๑

hans forlovede statskirken, og de kunne således som tilhørende forskellige trossamfund kun vies borgerligt). Et indledende problem var dog, at en ny fattiglov forlangte, at alle udlændinge, som ville indgå ægteskab i Danmark, skulle fremvise en erklæring fra deres hjemland om, at landet ville tage imod dem, i fald de ikke kunne forsørge sig selv og at dette også gjaldt deres kone og børn (herunder, hvis indvandreren døde). Den unge araber kunne ikke skaffe en sådan erklæring, simpelthen fordi hans forældre tilhørte en stamme uden fast tilhørsforhold, og at han dermed ikke vidste, hvor han var født. Der var dog tilløb til, at bestemmelsen kunne lempes, men et nyt problem opstod. Araberen ville løse kongebrev, og dette kunne han kun gøre, hvis han blev viet kirkeligt. Araberen og hans forlovede måtte således prøve at blive gift $i$ en anden hovedstad.

Historien er interessant, både fordi den understreger interessen for artisternes «erotiske kapital» (Hakim 2011), men også, fordi den understreger, hvor svært samtidens lovgivning bl.a. havde med at håndtere personer, som havde muslimsk baggrund. Dette er en problematik, som jeg vil vende tilbage til i det næste afsnit. Pressens fremhævelse af de kurtiserende (og nogle gange langt mere end det) møder mellem mandlige artister og kvindeligt publikum, finder vi i flere artikler og på tværs af udstillingerne. En historie, som bragtes i flere dagblade i 1899, omhandler således, hvordan en mandlig artist fra truppen «Mahdiens Krigere» var forsvundet med en københavnsk kaffehandlers hustru (se fx Holstebro Dagblad 1899; Aalborg Stiftstidende 1899). Hvorvidt der var tale om bortførelse eller en frivillig handling var aviserne ikke helt enige om. Under alle omstændigheder var sagen meldt til politiet, og skabte tydeligvis stor opmærksomhed.

Også i forbindelse med abessiniernes landsby i Aarhus i 1909 blev de udstilledes tiltrækningskraft fremhævet. Aalborg Stiftstidende pointerede således i sin beskrivelse af udstillingen, at «Mændene koketterer drevent med de hvide Damer!»(«Strix» 1909). Men de seksualiserede beskrivelser af udstillingens deltagere fik en yderligere drejning i bl.a. Nordjyllands Socialdemokrat, som fremhævede «Erotisk Kuller» blandt særligt damer af det bedre borgerskab i deres møde med Abessinierne:

Det er Abessinierne paa Landsudstillingen, som synes ganske at have fordrejet Hovedet paa adskillige Kvinder, der benytter enhver Lejlighed til at flokkes om og gnide sig op af de grinene Sorte, der selvfølgelig føler sig meget smigrede ved pludselig at føle sig saa eftertragtede. Undertiden bliver den kvindelige Paatrangenhed saa hed og nargaaende, at de Sorte ligefrem maa benytte Magt for at befri sig for de «kulrede» Damer (Nordjyllands SocialDemokrat 1909)

Artiklen fremførte en tydelig kritik af overklassens damer. For det var ikke - og avisen roste denne gruppe kvinder - arbejderklassens hustruer og døtre, som var til fals. Der har her sikkert haft betydning, at der var tale om artikel i en socialdemokratisk avis. Fremhævelsen af, at borgerskabets kvinder ikke kunne styre deres seksuelle lyster i mødet med de fremmede artister, indeholdt en slet 
skjult kritik af netop borgerskabet. For borgerskabets kvindeideal hyldede jo den dydige kvinde, hvis seksualitet var tøjret indenfor ægteskabets rammer. Temaet om mødet mellem mandlige artister og (svage) kvinder var i øvrigt et tema, som ikke kun vedrørte udstillingerne af personer, som kom fra den arabiske og muslimske verden. Også under udstillingen «Kina i Tivoli» 1902 var der diskussion af dette. I forbindelse med Kina udstillingen var det dog ikke overklassens kvinder, men derimod arbejderklassens kvinder, som blev kritiseret for ikke at kunne styre sig (Politiken 1902). Folkeudstillinger som sådan gav altså mulighed for at se på en kulturelt «anden» $\mathrm{i}$ et seksualiseret lys, samtidigt med, at det fremhævede en forståelse af kvinder som let erotisk påvirkelige, for ikke at forglemme, gav mulighed for kritik af visse samfundsklasser som «degenererede» og uden evne til at opfylde egne idealer.

\section{Araberne og deres religiøse praksis}

Et sidste tema skal behandles i denne artikel, og det er den religiøse praksis, som folkeudstillingerne af mennesker fra arabiske og muslimske lande bragte med sig. I modsætning til samtidens blik på de udstilledes vildskab og erotiske tiltrækningskraft var religion tydeligt et underordnet tema. Ikke dermed sagt, at religion ikke var en del af udstillingerne. Under beduinerkaravanen i Tivoli i 1897 skrev Social-Demokraten således blandt andet, at:

Inde på Arenaen drager en Ørkenkaravane, en Rakke arvardige Kameler, som bevager sig med gammeltestamentlig Vardighed; på deres høje Pukler gynger tilslørede Kvinder og fredsommelige Købmand fra Mekka. Karavanen slår Lejr, og Aftenbønnen bedes mod den nedgående Sol og den modsatte Ende løftet mod Tilskuerne.(Social-Demokraten 1897.Min fremhavelse)

Umiddelbart beskrives optrinnet som fred- sommeligt og som en modsætning til fremstillinger, der fremhæver arabere som vilde. Der er både gammeltestamentlige værdige kameler og fredsommelige mænd. Men freden brydes i de næste sætninger. En flok «vildtudseende $\emptyset$ rkenrøvere» rider i galop ind på scenen med løftede geværer. Karavanen overrumples og kvinderne hviner.

Abessiniernes landsby i 1909 er uden sammenligning den udstilling, hvor islam spillede den mest centrale rolle. I forbindelse med udstillingen blev der, sammen med hytter og værksteder, opført en (koran)skole, hvor en mullah underviste lejrens børn. Skolens eksistens dokumenteres af fotomateriale og beskrivelse i både pressen og udstillingens katalog (se fx Bender 2008: 194; Landsudstillingen i Aarhus 1909: 7-8; Aarhus Amtstidende 1909).

Kataloget nævner også en moske: «I et stille Hjørne af Landsbyen hæver sig højt over Beboelseshytterne Moskeens fire Taarne» (Landsudstillingen i Aarhus 1909: 8), men i modsætning til skolen er der ikke nogen fotografier, som bekræfter en sådan moskes eksistens. Det har heller ikke været muligt at finde avisartikler, som beskrev en sådan. I de arkitekttegninger af huse, restauranter og udstillingshaller, som blev anvendt under opbygningen af Landsudstillingen i Aarhus, findes der ingen tegninger af Abessiniernes Lejr, og moskeens eksistens kan således heller ikke bekræftes ad den vej. ${ }^{7}$ Det er derfor muligt, at der var en moske - og lige så muligt, at der ikke var.

Islam spillede således ikke den store rolle på udstillingerne, men af og til viste religionen alligevel sin betydning på anden vis. Som tidligere nævnt gav det fx problemer, da en af de arabere, som optrådte i Tivoli i 1892, ville gifte sig med en dansk kvinde. At han var muslim gjorde, at han ikke kunne løse kongebrev, selvom en lempelse i dette tilfælde blev en mulighed.

Påsamme måde kunne muslimsk identitet vise 
sig at være en forhindring, i de tilfælde, hvor et medlem af en af trupperne døde under sit ophold i Danmark, og skulle begraves. ${ }^{8}$ Dette var fx tilfældet, da Hadj Said, en ung artist, som optrådte i Cirkus Varieté, døde af blodforgiftning på Kommunehospitalet d. 17. juni 1895. Hadj Saids trup - som blandt andet indbefattede hans bror - havde svært ved at finde en kirkegård, hvor de kunne begrave liget. Det var først, da den franske generalkonsul blandede sig (Hadj Said var nemlig fra Algeriet, som da var en fransk koloni), at begravelsen kunne finde sted på Vestre Kirkegård. Begravelsen fik stor bevågenhed, ikke mindst i den socialistiske presse, som brugte begivenheden til at kritisere både jøder og kristne. Folkekirken og staten var, som det fremgår af følgende citat, under særlig beskydning. Begravelsen af en muslim blev således brugt til kritik af eksisterende samfundsstrukturer og -autoriteter:

Men hverken Jøder eller Kristne sender Guds uendelige Karlighed til alle Mennesker, naar der er Tale om en Muhamedaner eller anden ikke-statsanerkendt Religionsudøver ... [d] e tror jo alle paa en Gud. Des mere ubegribeligt er det, at en dansk Prast ikke vil assistere, nåret Guds barn skal begraves, at man endogsaa har Betankeligheder ved at give ham et Hvilested $i$ indviet Jord. (Social-Demokraten 1895)

I selvsamme artikel blev det beskrevet, at begravelsen blev udført efter muslimske forskrifter, og at der var sørget for, at kristne præster ikke blandede sig:

Begravelsen var uden al kirkelig Medvirken. Hadj Said var Muhamedaner, og for Folk af det Trossamfund har de danske Praster ingen Plads ... mens Mandene blottede deres Hoveder sankedes den 15 Kroners Kiste, på Hvis Laag det kristne Kors var erstattet af to Hander samlede $i$ broderligt Haandtryk. Ifølge Koranens Forskrifter var Liget lagt saaledes $i$ Graven, at Hadj Said vendte Ansigtet mod Øst, mod Profetens hellige By Mekka (Social-Demokraten 1895).

Islam var således ikke altid et centralt element i udstillingerne, men alligevel havde nogle af udstillingerne som konsekvens, at det omgivne samfund måtte forholde sig til en religiøs forskellighed, som det ikke var vant til at skulle håndtere. Det var fx tilfældet, når en af udstillingernes artister ville giftes eller skulle begraves.

\section{Afsluttende diskussion}

Jørgen Bæk Simonsen har om nogen været (og er fortsat!) en forsker, som har holdt fast i det historiske perspektiv, når det gjaldt mødet mellem det danske, det muslimske og det arabiske. Han har holdt fast $i$, at for at forstå islam og den arabiske verdens rolle i nutidens Danmark, må vi også inddrage fortidens møder, diskussioner og fortællinger. Dette er er et forskningsperspektiv, som nærværende artikel har bygget videre på igennem et fokus på folkeudstillinger imellem 1876-1909. Både folkeudstillinger som fænomen og samtidens presses beskrivelser heraf byggede tydeligt på forståelsen af Orienten som fremmedartet, farlig, eksotisk og erotisk.

Folkeudstillingerne gav samtidens danske befolkning, i særdeleshed i København og Aarhus, mulighed for at møde dette andet under former, som var kontrollerede og en del af en international underholdningsindustri. Udstillingerne antog en form, der bekræftede snarere end udfordrede samtidens forståelser. Men folkeudstillingerne dannede også baggrund for andre møder. Selvom beskrivelserne af kurtiserende møder mellem udstillede mænd og beskuende kvinder kan siges at både bygge på og genfortælle den eksisterende narrativ om Orienten, så understreger de også, at møder langt fra altid var kontrollerbare og at de fandt sted udenfor udstillingernes afgrænsede rum. Det var i sådanne tilfælde, at mødet mellem 
udstillet og beskuer for alvor blev grænseoverskridende, ikke mindst fordi der ikke eksisterede en præcedens for, hvordan man som samfund skulle håndtere, når en ung muslim ville gifte sig eller når en muslimsk artist døde og skulle begraves. Og selvom blandt andet det 19. århundredes folketællinger og andre typer af data understreger, at muslimer befandt sig i Danmark langt tidligere $\mathrm{i}$ forbindelse med folkeudstillingerne (Schmidt 2021), så understreger udstillingerne og deres «følgevirkninger» at sådanne møder havde forskelligt udtryk. Kombinerer vi disse eksempler med Jørgen Bæk Simonsens eksempler på samtidens intellektuelles møder med og fremstilling af islam og Orienten ser vi også, hvor flertydigt og forskelligartet disse møder var. Fra gadeplan til litteratur. Og understregningen af denne flertydighed, og den videre forskning heri, er vigtig for at forstå den rolle som både islam og den arabiske verden igennem historien har spillet i Danmark.

$$
\cdot f \cdot
$$

\section{REFERENCER ${ }^{9}$}

Udgivne kilder:

Aarhus Amtsavis (1909) «Abessinierne paa Landsudstillingen», 28. juni, s. 3 .

Aarhus Amtstidende (1909) «Fra Udstillingens

Enemærker», 22. maj, s. 2.

Tanja Kjær Andersen (2009) Folkekaravaner \& eksotiske mennesker - med sarligt fokus på fremvisninger i Danmark 18781909. Kandidatspeciale. København: Københavns Universitet.

Andreassen, Rikke (2015) Human Exhibitions. Race, Gender and Sexuality in Human Displays. Burlington: Ashgate.

Andreassen, Rikke (2014) «Danish Perceptions of Race and Anthropological Science at the Turn of the Twentieth Century», i The Invention of Race. Scientific and Popular Representations, Red. Nicolas Bancel, Thomas David, Dominic Thomas. New York: Routledge: 117-129. Andreassen, Rikke (2003) «The 'exotic' as mass entertainment: Denmark 1878-1909», Race \& Class årg. 45, nr. 2: 21-38.

Andreassen, Rikke \& Anne Folke Henningsen (2011)

Menneskeudstilling. Fremvisninger af eksotiske mennesker $i$ Zoologisk Have og Tivoli. København: Tiderne skifter.

Beduinen - Officielt Organ for Beduiner-Lejren i Danmark (1892).

Beduinen-Karawane (1892) København: A. W. Henningsens Tryk.
Bender, Johan (2008) Hurra for Århus! Landsudstillingen 1909vejene til og sporene fra. Risskov: Forlaget Klematis. «Blodin» (1899) «Mahdiens Krigere», Kjøbenhavns Adressecomptoirs Efterretninger, 14. august, s. 2. «Brian» (1892) «Københavnerier», i Bornholms Avis og Amtstidende, 13. august, s. 2.

Dannebrog (1896) «Tivolis Harem», 28. maj, s. 3. Dannebrog (1897a) «Tivoli og Beduinerkaravanen», 5. februar, s. 1 .

Dannebrog (1897b) «Beduinerne i Tivoli» 21. maj, s. 2. Dannebrog $(1897 \mathrm{C})$ «Et upåtalt Næringsmisbrug», 1. juli, s. 1.

Dannebrog (1899) «Vor Dagbog», 19. august, s. 4. Den til Forsendelse med de Kongelige Brevposter privilegerede Berlingske Politiske og AdvertissementsTidende (1892) «Beduinerkaravanen», 28. juli, s. 3. Hakim, Cathrine (2011) Erotic Capital: The Power of Attraction in the Boardroom and Bedroom. New York: Basic Books.

«Hjort» (1892) «Ørkenliv i København», Politiken, 5 . august, s. 1.

Hodeir, Cathrine (2014) «Human Exhibitions at World's Fairs Between Scientific Categorization and Exoticism? The French Colonial Presence at Midway Plaisance, World's Columbian Exposition, Chicago, 1893» $\mathrm{i}$ The Invention of Race. Scientific and Popular Representations, Red. Nicolas Bancel, Thomas David, Dominic Thomas. New York: Routledge: 222-232.

Holstebro Dagblad (1899) «Tips», 22. august, s. 2.

Kolding Folkeblad (1892) «En BeduinerKaravane», 5 . august, s. 2.

Kjøbenhavns Adressecomptiors Efterretninger (1892)

«Tivoli», 16. juli, s. 1 .

København (1897) «Cirkus Varieté», 12. februar, s. 3.

København (1899) «Kritik og Program», 12. august, s. 3.

Kjøge Avis (1892a) «Beduiner» 29. juli, s. 1.

Kjøge Avis (1892b) «For Beduinerne», 19. august, s. 1.

Landsudstillingen i Aarhus 1909 (1909) Abessiniens

Bjergboere. Aarhus: De Forenede Bogtrykkerier.

Lolland-Falsters Stifts-Tidende (1892) «Kjøbenhavns Tivoli», 2o. september.

Morgenbladet København (1892) «Beduinerne», 29, juli, s. 2.

«Moustache» (1892) «Ørkenrøvere i Reventlowsgade», Politiken, 28. juli, s. 2 .

«Moustache» (1897) «Arabien i Tivoli», Politiken, 17. juli, s. 1.

«Moustache» (1901) «Mellem Beduiner», Politiken, 30.

juni, s. 2.

Nielsen, Per (2015) Fru Jensen og andre vestindiske danskere. Dansk vestindiske sømand, tjenestefolk og arbejdere i Danmark 1880-1920. København: Nationalmuseet

Nordjyllands Social-Demokrat (1909) «Erotisk Kuller i Aarhus», 12. august, s. 1.

Rasmussen, Brian Traantoft \& Garbi Schmidt (2021)

«Eksotisk, farlig eller ønskværdig? Danskernes syn på

'kineseren' i årene 1896-1920», Historisk Tidsskrift årg. 121, nr. 1. s. 47-71.

Politiken (1902) «Det svage Køn og Tivolis Kinesere», 31. juli, $s$ 1.

Ribe Stifts-Tidende (1897) «Tivoli», 8. maj, s. 1.

Said, Edward W. (1979) Orientalism. New York: Vintage Books, 1979.

Schmidt, Garbi (2021) «Muslimer og muslimsk praksis i København 1863-1915: På sporet af en forsvundet historie» $\mathrm{i}$ 
Tidsskrift for Islamforskning/Scandinavian Journal of Islamic Studies, årg. 15 .

Simonsen, Jørgen Bæk (2004) Islam med danske øjne. Danskernes syn på islam gennem 1000 år. København: Akademisk Forlag.

Social-Demokraten (1895) «Hadj Saids Begravelse», 21. juni, s. 1.

Social-Demokraten (1897) «Beduiner i Tivoli», 18. juli, s. 2. Social-Demokraten (1899) «Tivolis aarlige Generalforsamling», 9. december, s. 2 .

Stocking, George W (1982) Race, Culture and Evolution: Essays in the History of Anthropology. Chicago: University of Chicago Press.

«Strix» (1909) «Udstillingen», Aalborg Stiftstidende, 15. juni, s. 1.

Aalborg Stiftstidende (1899) «En Bortførelse», 18. august, s. 1.

Ikke-udgivne kilder:

Landsudstillingens Bureau (1909a) Landsudstillingen i

Århus 1909: Fotos (1909-1909). Rigsarkivet.

Landudstillingens Bureau (1909b) Landsudstillingen $\mathrm{i}$

Århus 1909: Planer og tekniske tegninger (1908-1909).

Rigsarkivet.

Sankt Pauls Kirke. 1907-1912. Kirkebog.

Noter

1 Dette understreges fx af en notits i Dannebrog 1896 hvori det om den planlagte udstilling hedder at: «De skjønne Odalisker - alle kjøbenhavnske Ungmøer bevogtes selvfølgelig af barskudseende Haremsvogtere».

2 Andre danske forskere, som har beskæftiget sig med folkeudstillinger i en dansk sammenhæng indbefatter Andersen (2009), Schmidt (2021) og Rasmussen \& Schmidt (2021)

3 Adresseavisen Kjøbenhavns Adressecomptiors Efterretninger (1892) nævner specifikt truppen HadjAbdullah som optrædende i Tivoli.

4 De udstillede artister kom fra Sudan og talte arabisk (Dannebrog 1899).

5 Udstillingen blev dog i pressen anklaget for at været et «Skrabsammen» af forskellige nationaliteter, herunder en vicedirektør fra Yemen, og artister og personer, som arbejdede i værkstederne fra Ægypten og andre arabiske lande. Andre medlemmer af truppen blev beskrevet som «Somalinegere» og « Gallanegere» (Aarhus Amtsavis 1909)

6 Jeg vil i artiklen særligt tage udgangspunkt i materiale, som omhandlede følgende udstillinger: BeduinenKarawane (1892), Arabertrup Hadj Abdullah, Mahdiens Krigere (1901), og Abessiniernes Landsby (1909).

7 Planer, tekniske tegninger og fotos fra Landsudstillingen findes på Rigsarkivet (Arkivskaber: Landsudstillingens Bureau).

8 I forbindelse med udstillingen af abessiniernes landsby døde et lille barn på to år, Husein Robly. I begravelsesprotokollen fra Sankt Pauls Sogn i Aarhus beskrives han som «Søn af Kriger Muhamud Robly og Hustru Guilo Gulboti, født i Djibouti i Abessinien” (Sankt Pauls Kirke 1907-12). Der er ingen beskrivelse af dette dødsfald og begravelsen af den døde i dagspressen. På baggrund af både barns og forældres navn - og beskrivelser af udstillingen som sådan - giver det mening at antage, at Husein Robly var muslim.

9 En del avisartikler er skrevet under pseudonym. Disse er anført både i brødtekst og referenceliste i anførselstegn. 